Evaluation of the use of advanced ozone oxidative process in reducing the danger of environmental toxicity by the effluents from compounding pharmacy

Thais Francine de Freitas Oliveira ${ }^{1}$, Julia Carolina Soares ${ }^{l}$, Suellen Zucco Bez ${ }^{1}$, Heloiza de Braga $^{1}$, Qushmua-Alzahran ${ }^{2}$, Luciano Henrique Pinto ${ }^{3}$

${ }^{1}$ University of the Region of Joinville, Department of Pharmacy

${ }^{2}$ University of the Region of Joinville and Lovely Professional University India

${ }^{3}$ University of the Region of Joinville, Departments of Medicine, Nursing and Pharmacy

Corresponding author: Luciano Henrique Pinto

University of the Region of Joinville, Departments of Medicine, Nursing and Pharmacy

Rua Paulo Malschitzki,10, University Campus - Industrial District, CEP 89219-710

Joinville, Santa Catarina, Brazil

Tel: +55 (47) 3461-9000

Email: luciano.henrique@univille.br

Submetido em 05/07/2021

Aceito em 11/08/2021

DOI: https://doi.org/10.47456/hb.v2i2.35949

Health and Biosciences, v.2, n.2, ago. 2021

Disponível em: https://periodicos.ufes.br/healthandbiosciences 


\section{Oliveira et al.}

\section{ABSTRACT}

The presence of emerging pollutants in the waters has been worldwide observed, resulting from improper domestic disposal, veterinarian use, and product waste from pharmaceutical industries and compounding pharmacies. The contamination provoked, besides causing damage to the environment, remains in potable water even after passing through the treatment plants. The purpose of this work was to verify the existence of environmental toxicity of gross effluents from compounding pharmacy laboratories, as well as the same effluents treated with AOP (advanced oxidation processe) via ozone in the stated time of 1 hour, having as a risk parameter the changes caused in Euglena gracilis algae. Photosynthetic efficiency tests were conducted via PAM (pulse amplitude modulated), and chlorophyll concentration and behavioral evaluation were checked via NGTOX (New generation Tox). The results demonstrate that the hormone laboratory had the most impacted effluent treated, with the lowest production and significant chlorophyll reduction. It presented reduction in the photosynthetic activity post-ozonation, due to hormone decomposition, oxidative potential and ethylene formation. Effluents from psychotropic and solid laboratories presented different production demand, but similar follow-up, with impact on the algae's behavior and photosynthetic activity, due to the presence of substances acting on cellular action potentials. The treated effluent from dermocosmetics laboratory influenced the chlorophyll concentration, as well as the general speed and velocity of surface ascent. The behavioral differences of the algae's between the laboratories and the pre and post-ozonation conditions demonstrate that the effluent treatment should be distinguished, according to the characteristics of the manipulated substances in each laboratory.

Keywords: Biomonitoring. Euglena gracilis. Oxidative Process. Ozonation.

Health and Biosciences, v.2, n.2, ago. 2021

Disponível em: https://periodicos.ufes.br/healthandbiosciences 


\section{INTRODUCTION}

All over the world, the presence of medicines and residues of hygiene and health products has been identified in the waters, currently classified as emergent pollutants. This contamination is the result of many factors, such as improper domestic disposal; exacerbated veterinarian use, making the excretion of medicine active metabolites reach the groundwater in higher-than-expected quantities; and product waste from pharmaceutical industries and compounding pharmacies, that dispose their compounds to the effluents. Although the wastewater treatment plants treat this water, many medicines still remain in the drinking water (VERLICCHI et al., 2012).

In general, it has been observed that traditional wastewater treatment processes are not very efficient in removing this kind of emergent pollutants. In biological processes, for example, the degradation efficiency is highly influenced by the presence of other macrocompounds, what makes the drug degradation, besides rare, only partial (KOCKSCHULMEYER et al., 2011). Systems based on absorption processes have been recently proposed, which use standard (active carbon) and modern (pre-absorbed micelles in montmorillonite) sorbents. However, their efficacy is questionable (CRUZ, 2010).

In this perspective, investigations indicating the environmental risk of these pollutants and the methods of removing these contaminants are increasingly more needed, since neither the treatment approaches nor the awareness of this issue are enough. This includes the legislation which requires to be updated on the issue of emerging pollutants.

The Brazilian Water Resources Management Policy aims to assure the proper water availability to human consumption (BRASIL, 1997). The Order no. 2.914/11, of the Ministry of Health, defines the potability patterns to water consumption. In this document, the drugs with potential risk to human health are not mentioned (CORDEIRO, 2007). This condition makes the compounds neither identified nor even treated on the wastewater treatment plants (KUNKEL et al., 2012).

Contrasting with the Brazilian reality, organizations like European Union (EU), the United States Environmental Protection Agency (EPA) and the World Health Organization (WHO), have already published guidelines and legislations warning about the risks of the presence of medicines in the water and requiring studies leading to their removal, in order to establish acceptable limits for drinking water (ESPUGLAS et al., 2007).

In this scenario, there are the compounding pharmacies, which, in the last decade,

Health and Biosciences, v.2, n.2, ago. 2021

Disponível em: https://periodicos.ufes.br/healthandbiosciences 
handled $8 \%$ of all the prescriptions in Brazil (PINTO et al., 2016). Nowadays, there are more than 7,000 such establishments over the country, and they are responsible for the small-scale and personalized medicine production, following all the care and precautions required by the current legislation. Specifically in the city of Joinville (Santa Catarina, Brazil), this study site, currently, 25 compounding pharmacies are registered in the Conselho Regional de Farmácia and Vigilância Santitária local, regulatory agencies of pharmaceutical activities and sanitaries activities in Brazil, respectively. These pharmacies work from the traditional segment - meeting the demands of medicines and cosmetics, to those specialized, with veterinarian and hormone production.

When reaching the environment, the hormones are then called endocrine disruptors (ED). These ED are defined as natural or synthetic exogenous chemical substances that, when in the environment, are capable of modifying the endocrine system, since they simulate the actions of natural hormones. These compounds might cause disorders that affect human and animal health (KUNKEL et al., 2012), provoking, for example: breast and uterine cancer, increase in the incidence of polycystic ovarian, reduction in male fertility and prostatic neoplasm (FERREIRA, 2008). Considering the disorders that ED may cause in health and in the environment, their chemical removal is being widely studied.

A technique used to remove ED is based on the development of advanced oxidation processes (AOP), which corresponds to a type of water treatment. AOP promotes the formation of highly reactive and little selective hydroxyl radicals, being able to act on chemical oxidation of a wide range of organic substances, like medicines, converting them in substances that a priori, do not present the same biological interactions than the original molecule. In specific cases of ED like estradiol, the oxidizing action leads to decomposition of the pharmacophoric group and cessation of estrogenic activity (LOPEZ-SERNA et al., 2012).

A way to obtain the advanced oxidation is through the ozone, which is highly used along with other oxidizing agents, like hydrogen peroxide, titanium dioxide and the presence of ultraviolet light. These processes have been showing efficiency in emerging environmental decontamination (SHI, 2010).

The use of AOP in this case is justified by the previously presented points related to the need of reducing the environmental danger. However, it is important to say that compounds originated from degradation (COD) will be formed, and their evaluation will be relevant as well. The evaluation of the environmental impact provoked by these COD and the toxicity hazards in different trophic levels may clarify the use of this decontamination procedure and

Health and Biosciences, v.2, n.2, ago. 2021 
the results on the suppression of a certain environmental risk (MATIAS et al., 2021).

In this study it will be considered the results obtained by Pinto et al. (2016) with the algae of the genus Euglena gracilis in relation of the gross effluents from a hormone compounding laboratory after the ozone/ultraviolet AOP, analyzing the alterations and responses that COD may cause, relating with those found in other laboratories (psychotropic, dermocosmetic and solids).

\section{METHODOLOGY}

\section{Study design}

This study was carried out at the Photochemistry and Photobiology Laboratory and the Environment Laboratory at the University of the Region of Joinville - UNIVILLE. This was an experimental study involving the use of algae of the genus E. gracilis KLEBS obtained from the University of Göttingen's collection, Germany. Behavioral changes, photosynthetic activity and chlorophyll level alterations were evaluated, when the algae were submitted to chlorinated water from the pharmacy, as well as to the gross effluents and the post-ozone/UV-AOP effluents.

\section{Sample collection}

Three types of samples were analyzed and all of them were collected from the four pharmacy laboratories.

- Water from access: chlorinated, to be used as control;

- Gross effluent, collected from the pharmacy;

- Post-AOP - treated effluent.

In order to conduct the study, there was the collaboration of a compounding pharmacy from the city of Joinville, northeast of the state of Santa Catarina, the same facility that was part of Pinto et al.'s investigation (2016), which allowed the collection of samples from the four production environments of the pharmacy:

- Psychotropic laboratory, responsible for the compounding of controlled-sale medicine prescriptions, according to the Order 344/98;

- Hormone laboratory, responsible for the compounding of strictly hormonal

Health and Biosciences, v.2, n.2, ago. 2021

Disponível em: https://periodicos.ufes.br/healthandbiosciences 
prescriptions;

- Solids laboratory, responsible for the compounding of encapsulated and other solid formulations such as powders and granules;

- Dermocosmetic laboratory, responsible for the solids and semisolids formulation production of dermatological properties.

The samples classified as "water of access", were collected directly from the faucets of the washing sink in each laboratory, into a previously sterilized borosilicate glass jars. They were used as control samples (water from the wastewater treatment plant). The gross effluents samples were collected from the siphons connected to the washing sinks using a peristaltic pump, sterilized borosilicate glass jars were also used to store the samples. Samples were taken up to $12 \mathrm{~L}^{-1}$ from each laboratory. Afterwards, the samples were stored in polystyrene boxes with ice and away from light, until their packaging in the freezer.

\section{Estimate production of the compounding pharmacy laboratories}

In order to conduct the study, there was the collaboration of a compounding pharmacy from the city of Joinville, northeast of the state of Santa Catarina, Brazil, which allowed the collection of the samples from the four production environments of the pharmacy.

An important factor to be considered in the study is the quantity of actives and other substances disposed through the sinks and that compose the laboratories gross effluents. For this purpose, the pharmacy's average monthly production of six months was taken into account, and the monthly average production was calculated, in order to verify the laboratories' activity average, this calculation was made according to equation 1 :

$$
\text { (1) } \quad M P=\left(\frac{\sum \text { Monthly quantity oforders }}{30}\right) \times\left(\frac{\sum \text { mg oforders made }}{\text { quantity of orders }}\right)
$$

\section{Fractions tests preparation}

\section{$\underline{\text { Removal process }}$}

The removal reaction occurred in a $500-\mathrm{mL}^{-1}$ reactor, which contained the gross effluent samples from all the studied laboratories. The other removals were performed later, after 1-hour ozonation, through a Trump TCB ozone generator that injected the ozone in a $10-\mathrm{mg} \mathrm{L}^{-1}$ flow.

The total time was of 2 hours, in accordance with Ferreira (2008). The volume removed

Health and Biosciences, v.2, n.2, ago. 2021

Disponível em: https://periodicos.ufes.br/healthandbiosciences 
was up to $10 \%$ of the total volume $(50 \mathrm{~mL})$, following the recommendation, to avoid interferences related to a larger oxidizing agents' exposure to a smaller contaminant volume (ERZINGER et al., 2011). Afterwards, the samples were kept in a freezer to be later analyzed.

\section{Environmental toxicity hazard tests}

For the purpose of environmental toxicity hazard tests, 4 Categories of Samples were considered:

- Pure Algae culture;

- Access water;

- Gross effluent;

- Post AOP treated effluents.

\section{Tests with E. gracilis algae}

From each one of the four sample categories, a 5-mL aliquot was removed and added into a 40-mL E. gracilis algae culture, collections were performed for photosynthetic efficiency tests, chlorophyll concentration and behavioral evaluation via NGTOX (New Generation Tox) after a period of at least 48 hours, according to Ekelund (2008).

\section{Algae photosynthetic efficiency test via PAM}

In order to test the photosynthetic efficiency via PAM, the photosynthetic parameters were measured through a modulated pulse-width PAM 2000 fluorimeter (Walz, Effeltrich, Germany). The PAM measurement principle is based on changes in the chlorophyll fluorescence level, after the application of saturated light pulses. The yield of photosynthesis was, then, calculated accordingly to Equation 2, on Yield photosynthetic efficiency.

$$
\text { Yield }=\frac{f m-f 0}{f 0}
$$

Approximately $5 \mathrm{~mL}^{-1}$ of the tested cultures were taken and transferred to the cuvette of the PAM equipment. They were then submitted to saturating light pulse emission, for photosynthetic activity evaluation. The saturating light pulse emission made possible the detection of the maximal fluorescence $(\mathrm{Fm})$, indicating total reduction of the electrons PSII (photosystem stage II) receptor. The light-curve response was determined for all the treated 
samples. The algae were exposed to an increasing luminous intensity (generated by an internal halogen bulb) in 10 steps, from 0 to 3,111 molm-2/s. After $10 \mathrm{~s}$ of each luminous step, a saturating pulse was applied, and the photosynthetic yield and the electron transport rate (ETR) were measured automatically.

After the calculations of photosynthetic yield, the average yield in the test situation was calculated, taking into account all the values obtained in the saturation process. Global Photosynthetic Efficiency (GPE) was calculated according to Global Photosynthetic Efficiency Equation 3:

$$
G P E=\frac{\sum \text { Yeld during saturation }}{\text { Quantity of submitted irradiating pulses }} \times 100
$$

Thus, it was intended to analyze the interference that the constituents of gross effluents and the residues promote in the algae culture, when compared to the control one.

\section{Evaluation of algae behavioral changes through biomonitoring via NGTOX}

The behavioral tests with E. gracilis in the presence of the samples from the laboratories were conducted using a real-time biomonitoring tool called NG-TOX, developed and homologated by Ecobabitonga Tecnologia Ltda. The instrument has monitored, through the analysis of real-time images, the algae behavior, considering different movement parameters of the photosynthesizer unicellular flagellate (ERZINGER et al., 2011).

The equipment consists of a system of connections involving four silicone tubes responsible for (1) sucking E. gracilis cell culture, (2) water sample containing hormones for testing, (3) water for dilution of samples and (4) disposal of the analyzed material. Three pumps activated by peristaltic motors transported the cells, the diluents and the sample up to a glass cuvette of $22 \mathrm{~mm}$ of internal diameter and $0.2 \mathrm{~mm}$ of thickness. The trial bodies in contact with the control were blended and transferred to an observation cuvette, connected to a microscope, which captured the images of the cells in movement. The images were recorded by a charged coupled device camera and digitalized by a plate connected to a microcomputer, in which they were presented in a monitor. Then, the software calculated the movement parameters, the movement speed, the ascent rate, the average cell size, etc. Subsequently, samples from the laboratories were added separately, and after a period of 10 minutes, the parameters were analyzed by the software that compared them with the control. Any alteration on the

Health and Biosciences, v.2, n.2, ago. 2021

Disponível em: https://periodicos.ufes.br/healthandbiosciences 
movements, average speeds, ascent rates and cell size were calculated and compared with the previous results (HADER et al., 2012).

Test for alterations on concentration of chlorophyll present in algae: chlorophyll removal from the algae and $U V$ analysis (160 SHIMADZU)

This test had the objective to verify if the parameters previously analyzed affected the chlorophyll concentration. After the time of exposure to contaminants, 5-mL of the culture media submitted to the presence of the test samples and the control were taken. These aliquots were treated according with the procedures conducted by Sumida et al. (2007). Aliquots were vacuum-filtered through Whatman ${ }^{\circledR} 47-\mathrm{mm}$ filter paper.

The papers containing the filtered (precipitated cells) were transferred to a Falcon tube, received $5 \mathrm{ml}$ of ethanol and were kept at $4^{\circ} \mathrm{C}$ for 60 minutes, for the pigments extraction. Then, the mixtures were centrifuged at $6,000 \mathrm{~g}$ for 10 minutes, at $4^{\circ} \mathrm{C}$ in order to aggregate on the debris cells.

The absorption spectrum of the supernatant was measured according to Lorenz's equation to calculate the chlorophyll concentration.

\section{Data statistical analysis}

The data were evaluated through Analysis of Variance (ANOVA), a univariate technique that treats quantitative data in relation to a three-level categorical independent variable.

For the groups' analysis (tests and control), comparing all the effects, the used technique was an ANOVA extension, called ANOVA for repeated measures, which consists on a better developed approach for paired data. This part consists, therefore, of the comparisons of results and averages based on the quantitative items of their sampling.

The second part will consist of the description of the other variables, because formally there is no statistical hypothesis test in this part, although it serves to confirm or not a priori expectations about the results.

The statistical analysis on algae behavior evaluated via NG-TOX were conducted by ImagingTox ${ }^{\circledR}$, a software especially developed and written for Microsoft platform, with multilingual Net 64-bit and MS SQL Server database. It has seven threads (the main one, three for video 1 and three for video 2), two functions (one for controlling the PC and NG-TOX connection and the other one for database connection and validation), making possible the

Health and Biosciences, v.2, n.2, ago. 2021 
storage of bioassays performed for forensic analysis and real-time results exhibition screen. ImagingTox $®$ conducted the 5-PL integrated statistical analysis.

\section{RESULTS AND DISCUSSION}

The environmental toxicity related to emergent pollutants has been increasingly causing concern among the scientific community, especially because several studies have been pointing out to clear health and environmental risks (KUNKEL et al., 2012). Recent studies have fostered more researches in which the results were fundamental for the direction of other studies, as well as those that study the development of decontamination processes of these emerging products that are harmful to the environment. It then comes to have a scenario that directs the review and reorientation of conducts and legislation addressing environmental issues, both nationally and internationally (KOCK-SCHULMEYER et al., 2011).

In this perspective, compounding pharmacies are potent candidates to generate emergent pollutions potentially harmful to health and to the environment. Studies performed by the Agência Nacional de Vigilância Sanitária - ANVISA (National agency of sanitary activities in Brazil), have showed that in Brazil around 120 thousand tons of garbage is generated every day, and between 1 and $3 \%$ of this total is produced by health facilities, comprising the compounding pharmacies. And, about 10 to $25 \%$ of this health waste represents risks to the environment and to the population's health - including the medicines (BRASIL, 2014).

Among the aspects of the compounding pharmacy that served as effluent collection, an important factor to consider was the amount of actives and other substances disposed though the sinks and which compound the gross effluents from the laboratories. This study aimed not only to know the characteristic of the Hormone laboratory, but also of the other ones of the remain laboratories, in order to compare the found results and to evaluate the risk of the hormone compounding in the face of production and other factors. To be able to know how many items, the pharmacy averagely produced, the average monthly production of six months was examined, accordingly to Equation 1, previously presented.

The found results were collected and placed in a spreadsheet obtaining the following results (Table 1).

Health and Biosciences, v.2, n.2, ago. 2021 
Table 1. Quantity of formula produced between January and July of 2014.

\begin{tabular}{l|l|l}
\hline Laboratory & $\begin{array}{l}\text { Quantity of } \\
\text { formula }\end{array}$ & $\begin{array}{l}\text { Representation in } \\
\text { percentage (\%) }\end{array}$ \\
\hline Psychotropic & 3,150 & 18.6 \\
\hline Hormones & 728 & 4.3 \\
\hline Solids & 9,388 & 55.5 \\
\hline Dermatocosmetic & 3,638 & 21.5 \\
\hline Total & 16,904 & 99.9 \\
\hline Source: pharmacy's registers.
\end{tabular}

The results show a more pronounced production of the formulations classified as "solids", which include capsules and powders used orally. They represent more than half of all formulations produced in the evaluated period. Secondly, there are the "dermatocosmetic" formulations, which include among them creams in which a multiple of actives are incorporated to. In smaller quantity, there are the "Psychotropic" formulas - Order 344/98 substances, which according to the current legislation - RDC67/2007 (provides on good practices of compounding preparations for Human use in pharmacies), it requires a separate laboratory, as well as the hormones - the main object of this study. Regarding the compounding of hormones, almost all the formula (99\%) corresponded to the production of Estradiol valerate, a structural analogue of the $17 \beta$ estradiol used for many clinical conditions.

As the purpose of this investigation was to evaluate the impact of ED in the effluents and of the formed COD, a CGMS (Gas chromatography-mass spectrometry) analysis of the LMH (Hormones Laboratory) sample was conducted, in order to identify the presence of estradiol valerate ED, and another analysis was performed after ozone-based POA and UV for 120 minutes.

\section{Influence of CODs formed in treated effluents on the behavior and concentration of chlorophyll in algae, and the relation between these two variables}

The presence of hormones in the effluent has significantly affected the velocity of surface ascent rate, inhibiting it, as well as the r-value of algae (Figure 1). This phenomenon was similar to the one observed by Pinto et al. (2016).

Health and Biosciences, v.2, n.2, ago. 2021

Disponível em: https://periodicos.ufes.br/healthandbiosciences 


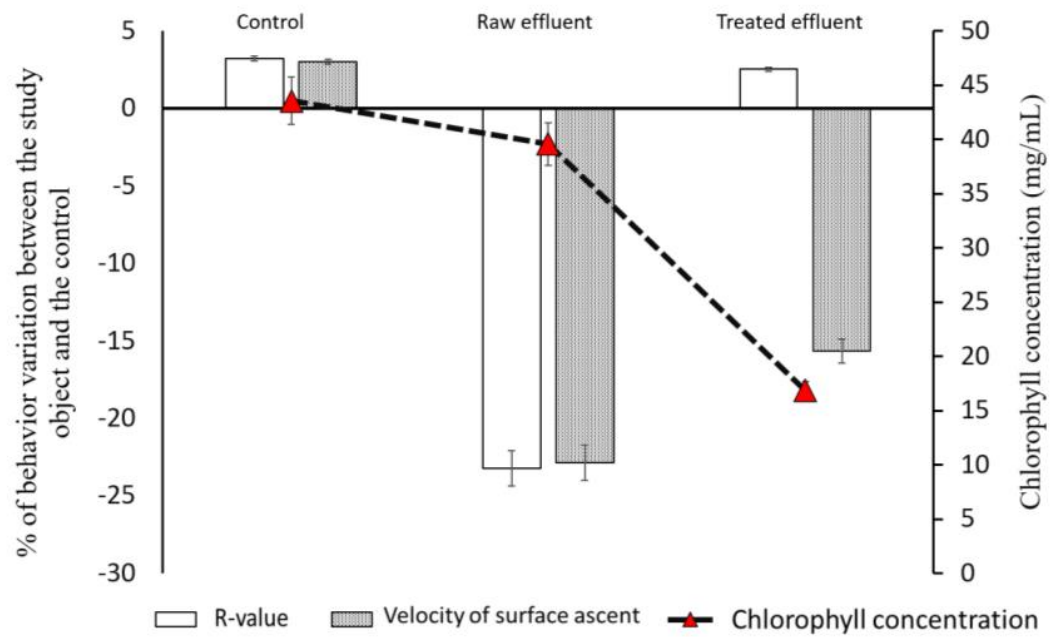

Figure 1. Changes in behavioral parameters of Euglenas gracilis exposed to post-ozonating effluents at the Laboratory of Hormones, compared to the raw effluent. Pearson correlation test: there are significant connections between the pairs of variables $(\mathrm{P}>0,050)$.

However, it is important to say that the COD, unlike the original ED, presents a certain potential of chlorophyll degradation.

To better comprehend this effect on chlorophyll degradation by COD, a comparison between the concentrations before and after the ozonating process was performed (Figure 2). Considering the influence over the chlorophyll concentration, it was seen a clear difference between the laboratories and the pre and post-ozonating, as it is possible to see:

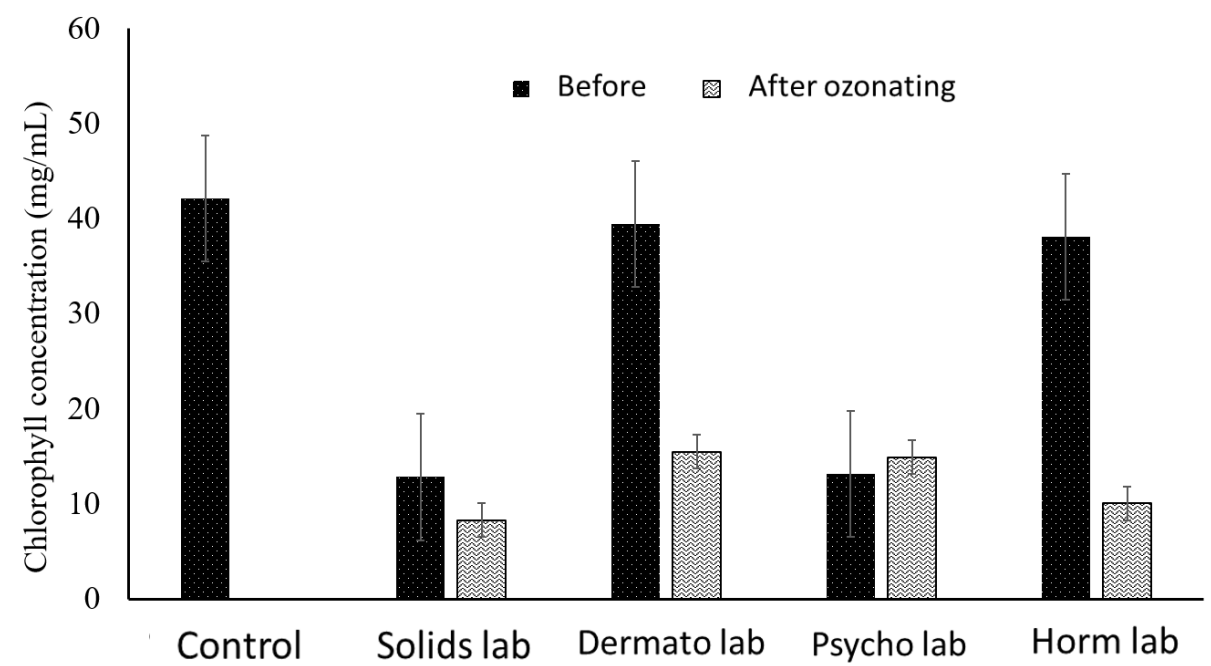

Figure 2. Influence on chlorophyll concentration. Variance analysis on Kruskal-Wallis variables. $\mathrm{H}=7.812$ with 2 liberty degrees. $\mathrm{P}$ (est.) $=0.020 \mathrm{P}$ (exact) $=0.011$. The difference among the average value between the treatment groups are greater than the expected. There is a statistically significant difference $(\mathrm{P}=0.011)$.

Health and Biosciences, v.2, n.2, ago. 2021

Disponível em: https://periodicos.ufes.br/healthandbiosciences 
In this comparison, it was seen that in the solids and psychotropic laboratories there were reductions in $a$-chlorophyll in the presence of raw effluent. The result was very similar when compared with the same waste treated using ozonating. However, in the dermatocosmetics laboratory, as well as in the Hormone laboratory, it was difficult to see the influence of raw effluent, but it was observed influence of the treated effluent, which now has a concentration similar to the ones from the other laboratories treated with ozone/UV. It is important to emphasize the ozone in excess was not present, because in reaction with potassium permanganate the result was negative for the ozone. The justification for the hormone laboratory was the antioxidating activity, while a probable explanation for the dermatocosmetics would be that the products handled in this laboratory are highly lipophilic, and of little influence on the physiology of algae (ARONSSON \& ECKELUND, 2005).

Another relevant variable is the quantity of actives and substances disposed through the sinks that constitute the raw effluent of the laboratories.

For this purpose, the average monthly production of six months of the pharmacy was considered, and the monthly average production was calculated, in order to verify the laboratories' pre-ozonating activity average. The results obtained according to Equation 1 (previously mentioned) are presented in Figure 3.

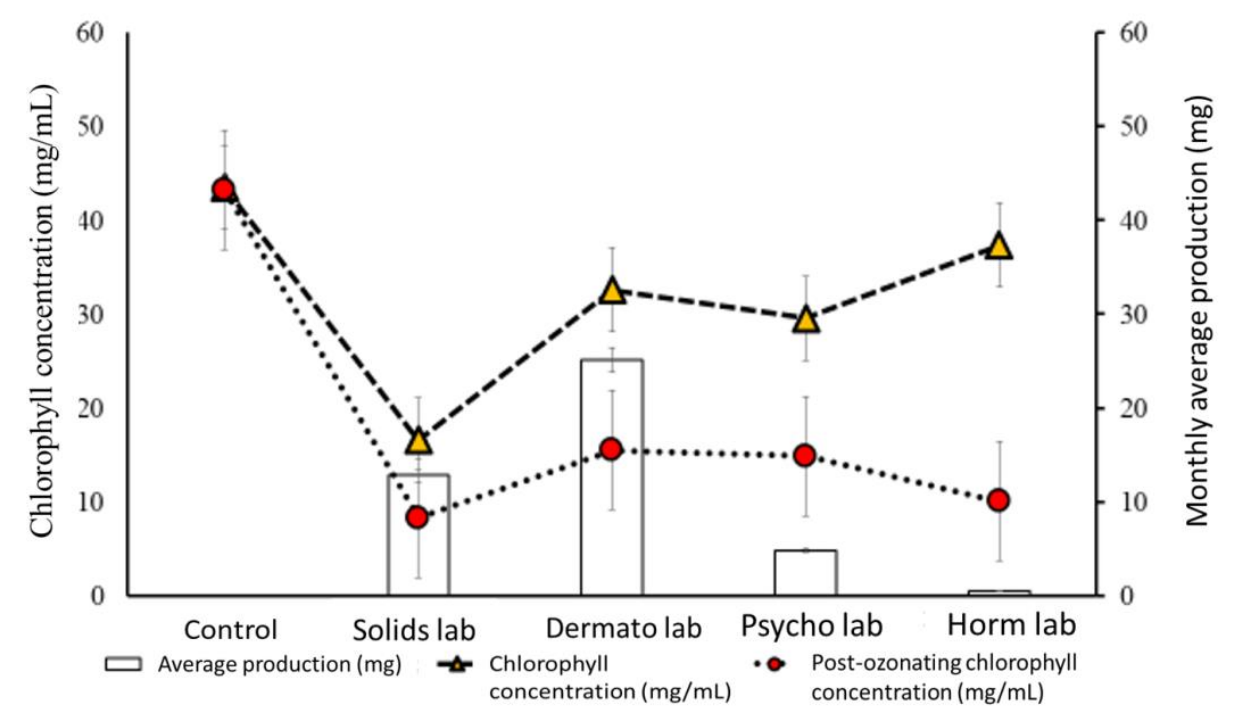

Figure 3. Influence of the produced quantity versus pre-ozonating chlorophyll concentration. Pearson correlation test: alteration on chlorophyll concentration at the laboratory $(\mathrm{P}>0,050)$.

The most impacting treated effluent that has COD, in an independent way on $a$ -

Health and Biosciences, v.2, n.2, ago. 2021

Disponível em: https://periodicos.ufes.br/healthandbiosciences 
chlorophyll concentration came from the laboratory of hormones, since it has the lowest production and significant reduction of $a$-chlorophyll concentration. At the same time, in the presence of raw effluent, its concentration was similar to the control one.

Therefore, it is clear that the removal process via ozone/UV, in the total estrogenic activity removal, interferes on $a$-chlorophyll degradation with the COD. Both the raw effluent and the treated one influence on $a$-chlorophyll concentration, reducing it, except at the hormone laboratory. The reduction of chlorophyll concentration might affect the algae's photosynthetic efficiency and cause ecotoxicity hazards, when there is not compensatory mechanism to assure the algae's survival. Anyway, the condition does not dispense the monitoring of effluents (HADER et al., 1985).

Thus, considering the reduction of $a$-chlorophyll concentration was strongly influenced by the COD, it was also pursued if these reductions would interfere on the global photosynthetic efficiencies of the post-ozonating samples, in order to confirm if the chlorophyll concentration influence anyhow this physiologic parameter, denoting one more risk/environmental hazards (Figure 4).

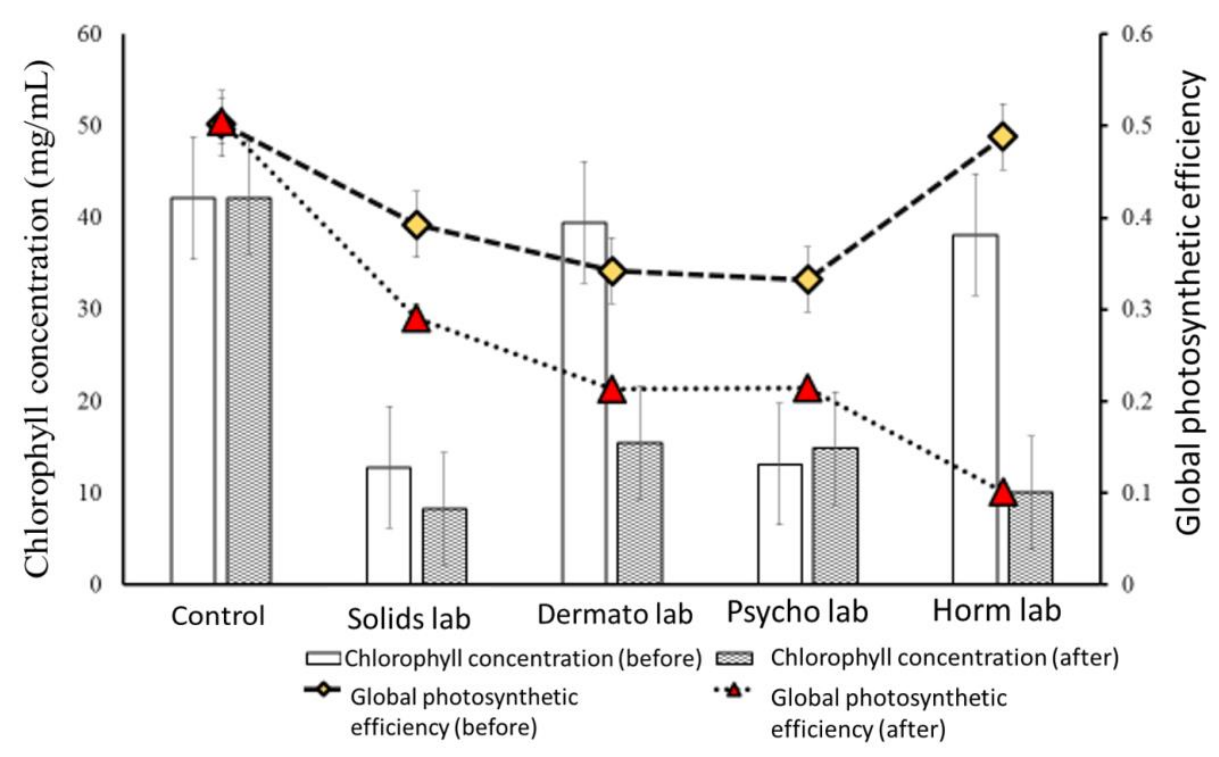

Figure 4. Comparison between chlorophyll concentration and global photosynthetic efficiency. Variance analysis on Kruskal -Wallis variables. $\mathrm{H}=7.812$ with 2 liberty degrees. $\mathrm{P}$ (est.) = $0.020 \mathrm{P}($ exact $)=0.011$. The difference among the average value between the treatment groups are greater than the expected. There is a statistically significant difference $(\mathrm{P}=0.011)$.

The global photosynthetic efficiency has presented variations among the raw effluent

Health and Biosciences, v.2, n.2, ago. 2021

Disponível em: https://periodicos.ufes.br/healthandbiosciences 
samples, revealing a direct correlation between the chlorophyll concentration and the global photosynthetic efficiency in all the laboratories, except in the hormones one, in which the probable antioxidating action attributed to the steroidal hormone structure helps the electrons transference and contributes to the global photosynthetic efficiency improvement (STACEY et al., 1996; PINTO et al., 2016).

The global photosynthetic efficiency was influenced by the COD in all laboratories, and the laboratory of hormones has showed the lowest value in the presence of COD and the highest difference between the efficiencies found in the exposure of raw effluents and the treated ones. The hormones' antioxidating activity has assured a good global photosynthetic efficiency performance. The reduction of global photosynthetic efficiency after the ozonation occurred because of the hormone decomposition and its oxidizing potential, as well as the possible ethylene formation, which affects the chlorophyll activity (STREIT et al., 2005).

Regarding the solids and psychotropic laboratories, the global photosynthetic efficiency reduction was due to the presence of substances that act on action potentials, listed in the production of both laboratories. These changes may influence the algae's movement ability, being an extra factor on the global photosynthetic efficiency, or the reduction is only attributed to the decline on chlorophyll concentration.

Maybe, the potential cellular action, attributed to the manipulated medicines in these laboratories prevent these mechanisms, which affect the algae's flagellar mobility (GOODMAN \& GILMAN, 2012).

\section{CONCLUSIONS}

The development of the present study made possible an analysis on how the ozonebased oxidative processes influence the reduction of the ecotoxicity risk caused by emergent pollutants. The obtained results have showed algae's behavioral changes among the four examined laboratories - Hormones, solids, dermocosmetics and psychotropic - comparing raw effluent samples, treated effluent samples and control.

Significant alterations on E. gracilis behavior were observed for the effluents from the laboratories of hormones and dermocosmetics, with modifications in general speed and velocity of surface ascent. The psychotropic and solids laboratories have not presented significant statistically difference over the algae's behavior. However, complementary studies are appropriate, in order to confirm the long-term toxicity, since the algae find compensatory

Health and Biosciences, v.2, n.2, ago. 2021

Disponível em: https://periodicos.ufes.br/healthandbiosciences 
mechanisms to fit the adversities.

The variations on algae's behavior due the exposure to different pollutants have suggested it is important to distinguish the effluent treatment, according with the characteristics of the substances manipulated in each laboratory, to reduce the environmental toxicity risks.

Therefore, the biomonitoring data found were important to have greater knowledge and awareness of the problem, indicating the possibility that environmental toxicity caused by effluents from compounding pharmacies may provoke great impact to the environment if revisions of actions and legislations are not performed in a way that in the long term minimize environmental issues related to this class of emerging pollutants.

This study was presented as an exploratory character in this relevant theme due to the statistical limitations faced. As it was described, it was carried out only in one compounding pharmacy and with a small collection frequency. It can be considered as an entry to this very important and still new theme, being recognized the importance of further studies with grater data and robustness.

For future studies, the evaluation of fish's behavior, before similar conditions, may also point out better comprehension over the influence of pharmaceutical ecosystem risks.

\section{ACKNOWLEDGMENTS}

The researchers thank Univille and the Research Support Funds, that make possible the Environmental Impacts Integrated Project (ECOSAM) development.

\section{REFERENCES}

1. ARONSSON KA, ECKELUND NGA. Effects on motile factors and cell growth of Euglena gracilis after exposure to wood ash solution: assentment of toxicity, nutrient, availability and pH-dependency. Water air soil pollut 162: 353-368, 2005.

2. BRASIL. Lei $\mathrm{N}^{\circ}$ 9.433, de 8 de Janeiro de 1997. Institui a Política Nacional de Recursos Hídricos, cria o Sistema Nacional de Gerenciamento de Recursos Hídricos, regulamenta o inciso XIX do art. 21 da Constituição Federa e altera o art. $1^{\circ}$ da Lei $n^{\circ} 8.001$, de 13 de março de 1990, que modificou a Lei nº 7.990, de 28 de dezembro de 1989. Brasília, DF, 1997. Available from: <http://www.planalto.gov.br/ccivil_03/leis/19433.htm> Accessed on July 1, 2021. 
3. BRASIL. Agência Nacional de Vigilância Sanitária. Anvisa e ABDI discutem descarte de resíduos de medicamentos. Available at: $<$ http://portal.anvisa.gov.br/wps/content/anvisa+portal/anvisa/sala+de+imprensa/menu+not icias+anos/2012+noticias/anvisa+e+abdi+discutem+descarte+de+residuos+de+medicamen tos>. Accessed on: July 1, 2021.

4. CORDEIRO D. Uso de bioindicador de efeito endócrino e validação do método para determinação de hormônios na água da represa municipal de São José. Dissertação (Mestrado em Química Analítica), Instituto de Química de São Carlos, Universidade de São Paulo, São Carlos, São Paulo, 2007, 90f.

5. CRUZ LH. Degradação fotocatalítica de Sulfametoxazol, Trimetropina e Diclofenaco em solução aquosa. Qim. nova 33(6): 1270-1274, 2010.

6. EKELUND NGA, NILSSON L. Effects of estrogenic substances on the movement of Euglena Gracilis. Internat. Verein. Theoret Angewand Limnol 30(2): 357-359, 2008.

7. ERZINGER GS, DEL CIAMPO L, HÄDER DP. Equipamento e Processo para Análise de Toxicidade em Sistemas Aquáticos. Instituto Nacional de Propriedade Industrial - INPI, $\mathrm{N}^{\circ} .0000221105523696,2011$.

8. ESPUGLAS S, BILA DM, KRAUSE LGT, DEZOTTI M. Ozonation and advanced oxidation technologies to remove endocrine disrupting chemicals (EDCs) and pharmaceuticals and personal care products (PPCPs) in water effluents. Journal of Hazardous Materials 149(3): 631-642, 2007.

9. FERREIRA MGM. Remoção da Atividade Estrogênica de $17 \beta$-Estradiol e de $17 \alpha$ Etinilestradiol pelos Processos de Ozonização e O3/H2O2. Tese (Doutorado em Engenharia Química) Universidade Federal do Rio de Janeiro, Rio de Janeiro, 2008, $173 f$.

10. GOODMAN \& GILMAN. As Bases Farmacológicas da Terapêutica. 12.ed, Porto Alegre: AMGH, 2012, 2079p.

11. HÄDER DP, LEBERT M. Real time computer controlled tracking of motile microorganisms. Photochem. Photobiol 42(5): 509-514, 1985.

12. KOCK- SCHULMEYER M, GINEBREDA A, POSTIGO C, LOPEZ-SERNA R, PEREZ S, BRIX R, LLORCA M, LOPEZ DE ALDA M, PETROVIC M, MUNNÉ A, TIRAPU L. Wastewater reuse in Mediterranean semi-arid areas: The impact of discharges of tertiary treated sewage on the load of polar micro pollutants in the Llobregat river (NE Spain). Chemosphere, 82(5): 670- 678, 2011.

13. KUNKEL U, RADKE M Fate of pharmaceuticals in rivers: Deriving a benchmark dataset

Health and Biosciences, v.2, n.2, ago. 2021

Disponível em: https://periodicos.ufes.br/healthandbiosciences 
at favorable attenuation conditions. Water Res 46(17): 5551-5565, 2012.

14. LOPEZ-SERNA R, PETROVIC M, BARCELO D. Occurrence and distribution of multiclass pharmaceuticals and their active metabolites and transformation products in the Ebro River basin (NE Spain). Sci. Total Environ 44: 280-289, 2012.

15. MATIAS ME, BEZ SZ, SOARES JC, PINTO LH. Avaliação da remoção de 17ß-estradiol por caldo enzimático de Pleurotus sajor-caju CCB019. HB 2(1): 98-108, 2021.

16. PINTO LH, CARDOZO G, SOARES JC, ERZINGER GS. Toxicidade ambiental de efluentes advindo de diferentes laboratórios de uma farmácia magistral. Rev. Ambient. Água 11(4): 819-832, 2016.

17. SHI W, WANG L, ROUSSEAU DP, LENS PN. Removal of estrone, 17alphaethinylestradiol, and 17beta-estradiol in algae and duckweed-based wastewater treatment systems. Environ Sci Pollut Res Int 17(4): 824-33, 2010.

18. STACEY A, MAOYUN TRAVI S. Estradiol-17 $\beta$ as an antioxidant: Some distinct features when compared with common fat-soluble antioxidants. J. lab. clin. med. 128(4): 367-375, 1996.

19. STREIT NM, CANTERLE LP, CANTO MW, HECKTHEUER LHH. As clorofilas. Cienc. Rural 35(3): 748-755, 2005.

20. SUMIDA S, LYMAN H, KIYOHARA N, OSAFUNE T. Mechanism of Conversion from Heterotrophy to Autotrophy in Euglena gracilis. Cytologia (Tokyo), 72(4): 447-457, 2007.

21. VERLICCHI P, AL AUKIDY M, ZAMBELLO E. Occurrence of pharmaceutical compounds in urban wastewater: Removal, mass load and environmental risk after a secondary treatment- a review. Sci. Total Environ 429(1): 123-155, 2012.

Health and Biosciences, v.2, n.2, ago. 2021

Disponível em: https://periodicos.ufes.br/healthandbiosciences 